\title{
FAKTOR-FAKTOR YANG BERPENGARUH TERHADAP KEJADIAN DIARE PADA BALITA DI WILAYAH PUSKESMAS CIHIDEUNG KOTA TASIKMALAYA TAHUN 2012
}

Oleh :

\author{
Dadan Yogaswara, SKM,MKM
}

\section{A. Abstrak}

Jumlah balita yang diperiksa dan didiagnosis terkena diare pada bulan JanuariFebuari 2012 yaitu 70 orang. Faktor-faktor yang diduga berpengaruh terhadap kejadian diare di puskesmas Cihideung adalah faktor lingkungan yang mencakup keberadaan jamban, dimana masih banyak balita yang menggunakan sarana pemandian umum. Faktor lain yang dapat meningkatkan kejadian diare adalah pendapatan orang tua dan status gizi. Tujuan penelitian untuk mengetahui Faktor-faktor yang berpengaruh terhadap kejadian diare pada balita di Wilayah Puskesmas Cihideung Kota Tasikmalaya tahun 2012

Penelitian ini menggunakan metode penelitian survei analitik dengan pendekatan cross sectional. Populasi dalam penelitian ini adalah semua balita yang berada di wilayah kerja puskesmas Cihideung tahun 2012. Sampel dalam penelitian ini adalah balita yang berada di wilayah kerja puskesmas Cihideung dan diperiksa di puskesmas Cihideung pada bulan Mei 2012. analis yang digunakan adalah Analisis univariat menghasilkan distribusi, frekuensi, dan proporsi dari berbagai karakteristik. Disajikan dalam bentuk tabel dan grafik. Untuk mengetahui adanya hubungan antara variabel yang diteliti maka digunakan analisis data dengan menggunakan rumus Chi square.

Hasil penelitian didapatkan responden yang menderita diare 18 balita dan tidak diare 45 balita. Status gizi di puskesmas Cihideung kota Tasikmalaya yang tergolong gizi lebih 2 balita, gizi baik 43 orang, gizi kurang 15 dan gizi buruk 3 balita. Mayoritas responden mempunyai pendapatan lebih dari UMR $(66,7 \%)$ dan sebagian besar masyarakat mempunyai perilaku baik terhadap kesehatan (61,9\%).Serta terdapat hubungan yang signifikan antara status gizi dengan kejadian diare pada balita,terdapat hubungan yang signifikan antara pendapatan orang tua dengan kejadian diare pada balita, terdapat hubungan yang signifikan antara perilaku dengan kejadian diare pada balita.

Kesimpulan penelitian ini terdapat hubungan yang signifikan antara status gizi,pendapatan orang tua, serta perilaku dengan kejadian diare pada balita. Meningkatkan pendidikan kesehatan terutama tentang pengertian diare, penyebab, cara penularan, dan pencegahan kepada masyarakat, sehingga dapat menambah pengetahuan masyarakat tentang penyakit diare. Kata Kunci : status gizi,pendapatan orang tua, perilaku serta kejadian diare
pada balita 


\section{B. Latar belakang}

Penyakit diare atau berak mencret merupakan salah satu penyakit yang sering menyerang bayi dan balita (Suririnah, 2004). Penyakit ini seringkali dianggap penyakit biasa oleh masyarakat. Berdasarkan laporan UNICEF (2002), hampir satu juta bayi dan anak balita diseluruh dunia meninggal karena diare setiap tahunnya (Kusyanto, 2006). Menurut WHO, diare membunuh dua juta anak setiap tahunnya (Kuls, 2001). Di Indonesia, kematian balita akibat diare merupakan yang tertinggi kedua setelah malnutrisi yaitu sekitar 100.000 anak. Bahkan kematian akibat malnutrisi juga tidak lepas dari serangan diare (Khaerudin, 2006).

Berdasarka survei Depkes RI, angka kesakitan diare untuk seluruh golongan umur berkisar 120-360 per 1.000 penduduk, balita menderita satu atau dua kali episode diare setiap tahun dan sebagian besar menyebabkan kematian pada balita 76 persen sedangkan kematian pada bayi diperkirakan 15,5 persen. Kejadian luar biasa (KLB) diare tahun 2005 tercatat paling banyak di profinsi Nusa Tenggara Timur, yakni tiga KLB dengan jumlah penderita mencapai 2194 orang dan jumlah yang meninggal 28 orang. NTT merupakan daerah dengan tingkat penderita diare tertinggi karena perilaku hidup bersih masyarakat disana masih memprihatinkan (Khaerudin, 2005).

Kepala Bidang P2M Dinas Kesehatan Kabupaten Garut, Firmanullah tahun 2005 mengingatkan faktor-faktor berupa kondisi sosial ekonomi masyarakat, keadaan gizi, serta perilaku masyarakat yang secara langsung atau tidak langsung, dapat mempengaruhi penyakit ini. Dia juga mengatakan bahwa penyakit diare di Indonesia merupakan salah satu masalah kesehatan yang utama (John, 2005).

Dinas Kesehatan Jawa Barat menyebutkan, dari Januari hingga pertengahan Desember 2006 baru 11 persen dari 13 persen target kasus diare yang dilaporkan dan ada kecenderungan meningkat dari tahun sebelumnya yang mencapai 671.467 kasus (Kusyanto, 2006). Menurut data WHO, sebanyak 100 juta jiwa di Indonesia masih mempunyai akses yang rendah terhadap sanitasi air bersih. Akibatnya, buruknya penyediaan air bersih dan sanitasi ini meyebabkan 23 per 100 ribu penduduk di dunia meninggal akibat penyakit diare dan mayoritas adalah balita (Indiono, 2006).

Berdasarkan laporan tahunan Dinas Kesehatan Kota Tasikmalaya, cakupan penderita diare pada tahun 2005 mencapai $3480 \quad(11,73 \%)$ balita (Laporan tahunan Dinas Kesehatan Tasikmalaya, 2005). Cakupan penderita diare pada balita di puskesmas Cihideung pada tahun 2006 menunjukkan angka 414 balita.

Wilayah kerja puskesmas Cihideung meliputi tiga kelurahan yaitu, Tuguraja, Tugujaya dan Nagarawangi. Jumlah balita yang diperiksa dan didiagnosis terkena diare pada bulan JanuariFebuari 2012 yaitu 70 orang. Faktorfaktor yang diduga berpengaruh terhadap kejadian diare di puskesmas Cihideung adalah faktor lingkungan yang mencakup keberadaan jamban, dimana masih banyak balita yang menggunakan sarana pemandian umum. Faktor lain yang dapat meningkatkan kejadian diare adalah pendapatan orang tua dan status gizi. Berdasarkan status pekerjaannya, sebanyak 36,45\% penduduk di wilayah kerja puskesmas cihideung bermata pencaharian sebagai buruh. Pendapatan orang tua yang kurang dapat mempengaruhi persoalan gizi yang dikonsumsi oleh balita. Dari 70 balita yang diare, 15 orang diantaranya menderita gizi kurang.

Berdasarkan data diatas, maka penulis merasa tertarik untuk melakukan suatu penelitian mengenai faktor-faktor yang berpengaruh terhadap kejadian diare pada balita di Puskesmas Cihideung kota Tasikmalaya tahun 2012. 
Tujuan penelitian untuk mengetahui gambaran faktor-faktor yang berpengaruh terhadap kejadian diare

\section{Metode}

Penelitian ini menggunakan metode penelitian survei analitik dengan pendekatan cross sectional. Populasi dalam penelitian ini adalah semua balita yang berada di wilayah kerja puskesmas Cihideung tahun 2012. Sampel dalam penelitian ini adalah balita yang berada di wilayah kerja puskesmas Cihideung dan diperiksa di puskesmas Cihideung pada bulan Mei 2012.

Jenis data yang dikumpulkan adalah data primer yaitu diambil langsung dari responden. Pengambilan data dilakukan dengan cara memberikan kuesioner. Pertanyaan dibuat dalam bentuk pertanyaan tertutup dengan alasan mempermudah responden dalam menjawab pertanyaan dan memudahkan peneliti dalam mengolah data. Selain itu pengumpulan data juga dilakukan dengan menimbang berat badan balita menggunakan timbangan dan di ukur dengan menggunakan standar NCHS untuk menentukan status gizi balita.

Pengolahan Data

1. Pemeriksaan data (Editing)

Meneliti kembali apakah isian pada lembar kuesioner sudah cukup baik dan dapat segera diproses lebih lanjut.

2. Pemberian kode (Coding)

Mengklasifikasikan jawaban-jawaban yang ada menurut macamnya ke bentuk yang lebih ringkas dengan menggunakn kode-kode.

3. Pemasukan data (Entry Data)

Data yang telah dikelompokan sesuai dengan jawaban responden maka data tersebut di pindahkan ke dalam komputer untuk diolah.

4. Penyusunan data (Tabulating) pada balita di puskesmas Cihideung kota Tasikmalaya.

Proses penyusunan sedemikian rupa sehingga memudahkan dalam penjumlahan data dengan menggunakan program komputer SPSS 11.0 dan disajikan dalam bentuk tabel-tabel dan di uji dengan Chi square.

Analisis Data

Data yang diperoleh akan di analisa dan diinterpretasikan untuk menguji hipotesis dan diolah menggunakan:

1. Analisis Univariat

Analisis univariat dilakukan terhadap tiap variabel dan pada umumnya dalam analisis ini menghasilkan distribusi, frekuensi, dan proporsi dari berbagai karakteristik atau variabel yang diteliti yaitu: status gizi, perilaku hidup, sosial ekonomi dan lingkungan. Disajikan dalam bentuk tabel dan grafik.

2. Analisis Bivariat

Untuk mengetahui adanya hubungan antara variabel yang diteliti maka digunakan analisis data dengan menggunakan rumus Chi square, yaitu untuk menguji apakah frekuensi yang terdapat pada masing-masing sampel berbeda secara signifikan atau hanya kesalahan pengambilan sampel. Chi square dapat digunakan untuk menganalisis dua atau lebih sampel yang diteliti.

Rumus Chi Square :

$$
\mathrm{x}^{2}=\sum\left[\frac{(f o-f h)^{2}}{f h}\right]
$$

Keterangan : $\mathrm{x}^{2}=$ Chi square

$f_{o}=$ Frekuensi yang

diperoleh

diharapkan

$f h=$ Frekuensi yang

$$
\sum=\text { Sigma }
$$




\section{Hasil penelitian}

1) Hasil Pemeriksaan

Tabel 2

Distribusi Frekuensi Responden Berdasarkan Pemeriksaan Balita di Puskesmas Cihideung Kota Tasikmalaya

Mei 2012

\begin{tabular}{|c|c|c|c|}
\hline No & Status Diare & Jumlah & Persen \\
\hline 1. & Diare & 18 & 28,6 \\
\hline 2. & Tidak Diare & 45 & 71,4 \\
\hline \multicolumn{2}{|c|}{ Total } & 63 & 100,0 \\
\hline
\end{tabular}

Berdasarkan tabel 2 diatas dapat diketahui bahwa hasil pemeriksaan terhadap 63 responden di puskesmas Cihideung menunjukan 71,4 persen tidak mengalami diare dan 28,6 persen responden mengalami diare.

2) Status Gizi

Tabel 3

Distribusi Frekuensi Responden Berdasarkan Status Gizi Balita di Puskesmas Cihideung Kota Tasikmalaya

Mei 2012

\begin{tabular}{|c|c|c|c|}
\hline No & Status Gizi & Jumlah & Persen \\
\hline 1. & Lebih & 2 & 3,1 \\
\hline 2. & Baik & 43 & 68,3 \\
\hline 3. & Kurang & 15 & 23,8 \\
\hline 4. & Buruk & 3 & 4,8 \\
\hline \multicolumn{2}{|c|}{ Total } & 63 & 100,0 \\
\hline
\end{tabular}

Berdasarkan tabel 3 diatas dapat diketahui bahwa hasil pengukuran status gizi terhadap 63 responden menunjukan 3,1 persen mengalami gizi lebih, 68,3 persen mengalami gizi baik, 23,8 persen mengalami gizi kurang dan 4,8 persen mengalami gizi buruk.

3) Pendapatan

Tabel 4

Distribusi Frekuensi Responden Berdasarkan Pendapatan Orang Tua di Puskesmas Cihideung Kota Tasikmalaya

Mei 2012

\begin{tabular}{|c|c|c|c|}
\hline No & Pendapatan & Jumlah & Persen \\
\hline 1. & Kurang dari UMR & 21 & 33,3 \\
\hline 2. & Lebih dari UMR & 42 & 66,7 \\
\hline \multicolumn{2}{|c|}{ Total } & 63 & 100,0 \\
\hline
\end{tabular}

Berdasarkan tabel 4 diatas dapat diketahui bahwa hasil pengukuran pendapatan orang tua terhadap 63 responden menunjukan 33,3 persen pendapatan orang tuanya kurang dari UMR sedangkan 66,7 persen pendapatan orang tua balita lebih dari UMR.

4) Perilaku 
Tabel 5

Distribusi Frekuensi Responden Berdasarkan Perilaku di Puskesmas Cihideung Kota Tasikmalaya

Mei 2012

\begin{tabular}{|c|c|c|c|}
\hline No & Perilaku & Jumlah & Persen \\
\hline 1. & Baik & 39 & 62,0 \\
\hline 2. & Buruk & 24 & 38,0 \\
\hline \multicolumn{2}{|c|}{ Total } & 63 & 100,0 \\
\hline
\end{tabular}

Berdasarkan tabel 5 diatas dapat diketahui bahwa perilaku dari 63 responden menunjukan 62,0 persen perilaku baik dan 38,0 persen perilakunya buruk.

Analisis Bivariat

1) Hubungan antara status gizi dengan kejadian diare

Tabel 6

Hasil Analisis Statistik Responden Yang Menderita Penyakit Diare

Berdasarkan Status Gizi di Puskesmas Cihideung

Kota Tasikmalaya Mei 2012

\begin{tabular}{|c|c|c|c|c|c|c|c|}
\hline Status Gizi & \multicolumn{2}{|c|}{ Diare } & \multicolumn{2}{|c|}{ Tidak Diare } & \multicolumn{2}{c|}{ Total } & P Value \\
\cline { 2 - 8 } & $\mathrm{F}$ & $\%$ & $\mathrm{~F}$ & $\%$ & $\mathrm{~F}$ & $\%$ & \\
\hline Lebih & 0 & 0 & 2 & 4,4 & 2 & 3,1 & \\
\hline Baik & 6 & 33,3 & 37 & 82,2 & 43 & 68,3 & \multirow{2}{*}{0,000} \\
\hline Kurang & 10 & 55,6 & 5 & 11,2 & 15 & 23,8 & \\
\hline Buruk & 2 & 11,1 & 1 & 2,2 & 3 & 4,8 & \\
\hline Total & 18 & 100,0 & 45 & 100,0 & 63 & 100,0 & \\
\hline
\end{tabular}

Berdasarkan tabel 6 diatas dapat diketahui bahwa penderita diare, persentase terbesar terdapat pada satus gizi kurang $(55,6 \%)$ lalu gizi baik $(33,3 \%)$, gizi buruk $(11,1 \%)$ dan lebih $(0,0 \%)$.

Berdasarkan hasil uji statistik Chi-Square dengan menggunakan SPSS. 13 antara status gizi dengan kejadian diare pada balita di Puskesmas Cihideung Kota Tasikmalaya diperoleh $\rho$ value

2) Hubungan antara pendapatan dengan kejadian diare

Tabel 7

Hasil Analisis Statistik Responden Yang Menderita Penyakit Diare Berdasarkan Pendapatan Orang Tua di Puskesmas Cihideung Kota Tasikmalaya Mei 2012

\begin{tabular}{|c|c|c|c|c|c|c|c|}
\hline \multirow{2}{*}{ Pendapatan } & \multicolumn{2}{|c|}{ Diare } & \multicolumn{2}{|c|}{ Tidak Diare } & \multicolumn{2}{c|}{ Total } & $\begin{array}{c}P \\
\text { Value }\end{array}$ \\
\cline { 2 - 7 } & $\mathrm{F}$ & $\%$ & $\mathrm{~F}$ & $\%$ & $\mathrm{~F}$ & $\%$ & \\
\hline Kurang dari UMR & 11 & 61,1 & 10 & 22,2 & 21 & 33,3 & \multirow{2}{*}{0,000} \\
\hline Lebih dari UMR & 7 & 38,9 & 35 & 77,8 & 42 & 66,7 & \\
\hline Total & 18 & 100,0 & 45 & 100,0 & 63 & 100,0 & \\
\hline
\end{tabular}

$(0,000)$ dengan $\alpha(0,05)$ dan harga Chi-Square $(18,102)$ serta harga kritik Chi-Square (7,815). Nilai tersebut menunjukkan harga ChiSquare > harga kritik Chi-Square dan harga $p$ value $<\alpha$ sehingga dapat disimpulkan bahwa terdapat hubungan yang signifikan antara status gizi dengan kejadian diare pada balita. (1) 
Berdasarkan hasil analisis hubungan antara pendapatan dengan terjadinya penyakit diare pada tabel 7 dapat diperoleh bahwa penderita diare banyak terdapat pada responden yang pendapatan orang tua kurang dari UMR $(61,1 \%)$ dibandingkan dengan responden yang pendapatan orang tua lebih dari UMR $(38,9 \%)$. Sedangkan pada yang tidak menderita diare banyak didapatkan pada responden yang pendapatan orang tua lebih dari UMR $(77,8 \%)$ daripada yang pendapatannya kurang dari UMR $(22,2 \%)$.
Berdasarkan hasil uji statistik Chi-Square dengan menggunakan SPSS. 13 antara pendapatan orang tua dengan kejadian diare pada balita di puskesmas Cihideung kota Tasikmalaya diperoleh $\rho$ value $(0,003)$ dengan $\alpha(0,05)$ dan harga ChiSquare $(8,75)$ serta harga kritik ChiSquare (3,841). Nilai tersebut menunjukkan harga Chi-Square > harga kritik Chi-Square dan harga $\mathrm{p}$ value $<\alpha$ sehingga dapat disimpulkan bahwa terdapat hubungan yang signifikan antara pendapatan orang tua dengan kejadian diare pada balita.

3) Hubungan antara perilaku dengan kejadian diare

Tabel 8

Hasil Analisis Statistik Responden Yang Menderita Penyakit Diare Berdasarkan Perilaku di Puskesmas Cihideung

Kota Tasikmalaya Mei 2012

\begin{tabular}{|c|c|c|c|c|c|c|c|}
\hline \multirow{2}{*}{ Perilaku } & \multicolumn{2}{|c|}{ Diare } & \multicolumn{2}{|c|}{ Tidak Diare } & \multicolumn{2}{|c|}{ Total } & \multirow{2}{*}{ P Value } \\
\cline { 2 - 7 } & $\mathrm{F}$ & $\%$ & $\mathrm{~F}$ & $\%$ & $\mathrm{~F}$ & $\%$ & \\
\hline Baik & 2 & 11,1 & 37 & 82,2 & 39 & 62,0 & \multirow{2}{*}{0,000} \\
\hline Buruk & 16 & 88,9 & 8 & 17,8 & 24 & 38,0 & \\
\hline Total & 18 & 100,0 & 45 & 100,0 & 63 & 100,0 & \\
\hline
\end{tabular}

Berdasarkan hasil analisis hubungan antara perilaku dengan terjadinya penyakit diare yang terdapat pada tabel 8 diperoleh bahwa pada diare banyak didapatkan pada responden yang perilakunya buruk $(88,9 \%)$ dibandingkan dengan responden yang perilakunya baik $(11,1 \%)$. Sedangkan pada yang tidak menderita diare banyak didapatkan pada responden yang perilakunya baik $(82,2 \%)$ daripada yang perilakunya buruk $(17,8 \%)$.

\section{E. Pembahasan}

1. Hubungan Status Gizi dengan Kejadian Diare

Gizi sangat dibutuhkan agar tubuh terhindar dari berbagai penyakit. Kekurangan gizi pada anak dapat menyebabkan turunnya daya tahan terhadap penyakit serta meningkatkan resiko kematian dan kesakitan dan mempengaruhi seseorang menderita diare. Penyebab utama kekurangan gizi
Berdasarkan hasil uji statistik ChiSquare dengan menggunakan SPSS. 13 antara perilaku dengan kejadian diare pada balita di Puskesmas Cihideung Kota Tasikmalaya diperoleh $\rho$ value $(0,000)$ dengan $\alpha(0,05)$ dan harga Chi-Square $(27,56)$ serta harga kritik Chi-Square $(3,841)$. Nilai tersebut menunjukkan harga Chi-Square > harga kritik ChiSquare dan $p$ value $<\alpha$. Sehingga dapat disimpulkan bahwa terdapat hubungan yang signifikan antara perilaku dengan kejadian diare pada balita.

pada balita pada umumnya oleh dua hal yaitu sebab langsung (melalui makanan dan penyakit infeksi) dan sebab tak langsung (kesulitan ekonomi rumah tangga untuk memenuhi kebutuhan pangan, kurang baiknya pola pengasuhan anak, dan kurang baiknya pelayanan kesehatan, dan rendahnya sanitasi lingkungan)

Berdasarkan hasil penelitian tentang status gizi pada balita di puskesmas 
Cihideung kota Tasikmalaya dengan menggunakan perhitungan $\mathrm{BB} / \mathrm{U}$ dari 63 responden dapat diketahui bahwa responden yang mempunyai gizi lebih 2 responden $(3,1 \%)$, gizi baik 43 responden $(68,3 \%)$, gizi kurang 15 responden $(23,8 \%)$, dan gizi buruk 3 responden $(4,8 \%)$. Sehingga dapat diketahui bahwa balita yang datang ke puskesmas Cihideung sebagian besar mempunyai gizi baik. Tapi balita yang mengalami gizi kurang dan gizi buruk masih tinggi dan hal ini mungkin disebabkan karena kurangnya pengetahuan masyarakat tentang pemenuhan kebutuhan makanan bergizi bagi balita dan kurangnya daya beli masyarakat untuk memenuhi kebutuhan makanan yang bergizi.

Berdasarkan hasil penelitian tentang hubungan antara status gizi dengan kejadian diare pada 63 responden yang telah dilaksanakan diperoleh hasil analisis bivariat bahwa responden yang mengalami diare lebih banyak terdapat pada responden yang mengalami gizi kurang 55,6 \%. Hal ini mungkin disebabkan karena pada balita yang mengalami gizi kurang lebih rentan terhadap penyakit. Secara statistik terdapat hubungan yang bermakna antara status gizi dengan kejadian diare pada balita karena diperoleh $\mathrm{p}=0,000$ dan harga Chi-Square $=18,102$. Status gizi sangat berpengaruh pada kejadian diare karena gizi yang kurang dapat menyebabkan kekebalan tubuh terhadap penyakit berkurang.

\section{Hubungan Pendapatan dengan \\ Kejadian Diare}

Pendapatan merupakan faktor yang paling menentukan kuantitas dan kualitas makanan. Rendahnya peningkatan pendapatan orang miskin dan lemahnya daya beli mereka sehingga tidak memungkinkannya untuk mengatasi kebiasaan makan dan cara-cara tertentu yang menghalangi perbaikan gizi yang efektif. Hal ini dapat berdampak langsung pada balita sehingga mereka tidak mendapatkan makanan yang sesuai dengan kebutuhan gizi dan jatuh pada keadaan kekurangan gizi. Kekurangan gizi dapat berpengaruh terhadap menurunnya daya tahan tubuh seseorang yang akhirnya akan mempengaruhi balita terkena diare.

Berdasarkan hasil penelitian tentang pendapatan orang tua pada balita di puskesmas Cihideung menurut UMR terhadap 63 responden diperoleh 33,3\% pendapatan orang tua responden kurang dari UMR dan 66,7 \% lebih dari UMR.

Hasil penelitian yang telah dilaksanakan diperoleh hasil analisis bivariat bahwa penderita diare sebagian besar pendapatan orang tuanya kurang dari UMR (61,1\%). Hal ini disebabkan karena kurangnya pendapatan dapat mempengaruhi daya beli orang tua terhadap makanan yang dikonsumsi oleh balita. Sehingga dapat disimpulkan bahwa secara statistik terdapat hubungan yang bermakna antara pendapatan orang tua dengan kejadian diare pada balita di Puskesmas Cihideung Kota Tasikmalaya.

Pada penelitian ini dilakukan analisis tabulasi silang antara pendapatan orang tua dengan kejadian diare. Hasilnya diperoleh nilai $\mathrm{p}=0,003$ dan harga Chi Square $=8,75$ yang berarti bahwa pendapatan orang tua dengan kejadian diare pada balita mempunyai hubungan dan secara statistik bermakna.

\section{Hubungan Perilaku dengan Kejadian Diare \\ Perilaku kesehatan merupakan hal-} hal yang yang berkaitan dengan tindakan atau kegiatan seseorang dalam memelihara dan meningkatkan kesehatannya (Notoatmodjo, 2003). Berdasarkan hasil penelitian terhadap 63 responden diperoleh 39 responden $(62,0 \%)$ berperilaku baik dan 24 responden $(38,0 \%)$ berperilaku buruk. Hal ini berdasarkan kuesioner yang telah dibagikan dan masing-masing soal mempunyai skor tertinggi 4 dan terendah 1. Kuesioner berjumlah 24 soal dengan nilai tertinggi yang didapatkan oleh responden 84 , nilai terendah 44 dan nilai 
rata-rata 69. Berdasarkan hasil analisis bivariat bahwa penyakit diare lebih banyak terdapat pada responden yang mempunyai perilaku buruk $(88,9 \%)$ daripada responden yang berperilaku baik $(11,1 \%)$. Hal ini mungkin disebabkan karena masyarakat kurang membiasakan balita untuk mencuci tangan. Selain itu, di wilayah puskesmas Cihideung masih banyak masyarakat yang menggunakan air sungai terbuka untuk minum, mandi dan membersihkan peralatan rumah

\section{F. Simpulan dan saran}

Berdasarkan hasil penelitian terhadap 63 orang responden mengenai faktor-faktor yang berhubungan dengan kejadian diare di puskesmas Cihideung kota Tasikmalaya, dapat diambil kesimpulan sebagai berikut :

1. Gambaran karakteristik internal yang diteliti meliputi hasil pemeriksaan, status gizi, pendapatan orang tua , dan perilaku. Berdasarkan hasil pemeriksaan dapat diketahui bahwa responden yang menderita diare 18 balita dan tidak diare 45 balita. Status gizi di puskesmas Cihideung kota Tasikmalaya yang tergolong gizi lebih 2 balita, gizi baik 43 orang, gizi kurang 15 dan gizi buruk 3 balita. Mayoritas responden mempunyai pendapatan lebih dari UMR $(66,7 \%)$ dan sebagian besar masyarakat mempunyai perilaku baik terhadap kesehatan $(61,9 \%)$.

2. Terdapat hubungan yang signifikan antara status gizi dengan kejadian diare pada balita

3. Terdapat hubungan yang signifikan antara pendapatan orang tua dengan kejadian diare pada balita

4. Terdapat hubungan yang signifikan antara perilaku dengan kejadian diare pada balita

\section{$\underline{\text { Saran }}$}

1. Meningkatkan pendidikan kesehatan terutama tentang pengertian diare, penyebab, cara penularan, dan pencegahan kepada masyarakat, sehingga dapat menambah pengetahuan masyarakat tentang penyakit diare. tangga. Pemberian makanan pada anak juga sangat mempengaruhi keadaan anak. Dimana anak yang dibiasakan makan sembarangan lebih rentan terhadap penyakit diare karena makanan itu tidak terjamin kebersihannya.

Pada penelitian ini di lakukan tabulasi silang sehingga dapat diperoleh bahwa secara statistik terdapat hubungan yang bermakna antara perilaku dengan kejadian penyakit diare dengan nilai $\mathrm{p}=$ 0,000 dan harga Chi-Square 27,56.

2. Melaksanakan upaya untuk memperbaiki perilaku hidup dalam rangka meningkatkan kesehatan yang optimal

\section{G. Referensi}

Abdoerrachman. (1998) Buku Kuliah I Ilmu Kesehatan Anak, Info Medika, Jakarta

Anonim. (2002) Pedoman hidup Sehat, United Nations Children's Fund, New York.

Arikunto, S. (2006) Prosedur Penelitian Suatu Pendekatan Praktek, Edisi Revisi VI, PT Rineka Cipta

DKK Tasikmalaya. (2004) Pedoman Pemberantasan Penyakit Diare, Depkes Direktorat Jendral Pemberantasan Penyakit Menular dan Penyehatan Lingkungan, Jakarta.

Indiono. (2006) Jatim Terpilih Jadi Tempat Awal Pencanangan Sanitasi Total, tersedia dalam: http://www.d-infokom-jatim.go.id diakses tanggal 12 Maret 2010.

Intanisa, F. (2006) Faktor-Faktor Yang Berhubungan Dengan Kejadian Diare Pada Bayi Usia 0-24 Bulan, Universitas Siliwangi Tasikmalaya (Skripsi). Tidak dipublikasikan.

John. (2005) P2M Garut Lacak Indikasi Wabah Diare, tersedia dalam: http://www.garut.go.id diakses tanggal 12 Maret 2010. 
Khaerudin. (2006) Setiap Tahun 100.000 Anak Mati Karena Diare di Indonesia tersedia dalam: http://www.kompas.com diakses tanggal 12 Maret 2010.

Kuls. (2001) Kampanye Gerakan Cuci Tangan Pakai Sabun, tersedia dalam: http://www.koalisi.org diakses tanggal 12 Maret 2012.

Kusyanto, A. (2006) Mewaspadai Diare Hidup Sehat Dengan Air Bersih tersedia dalam: http://pikiranrakyat.com diakses tanggal 12 Maret 2010.

Mengel, M. B, \& Schwiebert, L. P. (2001) Referensi Manual Kedokteran Keluarga, University Press, Yogyakarta.

Ngastiyah. (1997) Perawatan Anak Sakit, EGC, Jakarta

Notoatmodjo. (2002) Metodologi Penelitian Kesehatan, PT Rineka Cipta, Jakarta.
Notoatmodjo. (2003) Ilmu Kesehatan Masyarakat Prinsip-Prinsip Dasar, PT Rineka Cipta, Jakarta.

Sachar,D.B, et al. (1997) Buku Gastroenterologi, EGC, Jakarta.

Sarbini. (2004) Penderita Diare Terus Bertambah tersedia dalam: http://www.kompas.com diakses tanggal 11 Maret 2010.

Slamet, J. (2002) Kesehatan Lingkungan, Gadjah Mada, Jakarta.

Soegijanto, S. (2002) Ilmu Penyakit Anak Diagnosa dan Penetalaksanaan, Salemba Medika, Jakarta.

Suandi. (1999) Diit Pada Anak Sakit, EGC, Jakarta.

Suriadi \& Yuliani, R. (2001) Asuhan Keperawatan Pada Anak, CV Sagung Seto, Jakarta.

Suririnah. (2004) Diare Mendadak dan Penanganannya, tersedia dalam: http://www.infoibu.com diakses tanggal 12 Maret 2010. 